\title{
Perjumpaan yang Mengubahkan Ditinjau dari Teori Behavioristik
}

\author{
Hermina Maroa, Nathalia Randan
}

\begin{abstract}
Abstrak
Perjumpaan yang mengubahkan adalah pertemuan manusia dengan pribadi Pencipta. Sentuhan Allah kepada peserta didik dapat mengubahkan perilaku, dan kepribadiannya menjadi ciptaan baru yang disebut manusia baru. Saulus menjadi Paulus adalah perjumpaannya dengan Yesus Kristus secara pribadi. Guru membawa siswa dalam pembelajaran untuk mengalami perjumpaan yang mengubahkan tersebut. Hasil yang diharapkan adalah perubahan sikap dan tingkah laku siswa di dalam kelas, keluarga dan masyarakat.
\end{abstract}

Kata-kata kunci: behavioristic, perubahan, perjumapaan, Tuhan, B. F. Skinner

\section{Pendahuluan}

Teori behaviouristik adalah sebuah teori yang dianut oleh Gadge dan Berliner tentang perubahan perilaku sebagai hasil dari pengalaman. Beberapa ilmuan yang termasuk pendiri dan penganut teori ini antara lain adalah Thorndike, Watson, Hull, Guthrie, dan Skinner.

Teori ini lalu berkembang menjadi aliran psikologi belajar yang berpengaruh terhadap arah pengembangan teori dalam praktek pendidikan dan pembelajaran yang dikenal sebagai aliran behavioristik. Aliran ini menekankan pada terbentuknya perilaku yang tampak sebagai hasil belajar. Teori behavioristik dengan model hubungan stimulus responnya, mendukung orang yang belajar sebagai individu yang fasif. Respon atau perilaku tertentu dengan menggunakan metode pelatihan atau perilaku tertentu dengan menggunakan metode pelatihan atau pembiasaan semata. Munculnya perilaku akan semakin kuat bila diberikan penguatan dan akan menghilang bila dikenahi hukuman.

Belajar merupakan akibat adanya interaksi antara stimulus dan respon. Seseorang dianggap telah belajar sesuatu jika dia dapat menunjukkan perubahan perilakunya. Menurut teori ini dalam belajar yang penting adalah input yang berupa stimulus dan output yang berupa respon. Stimulus adalah apa saja yang diberikan guru kepada pelajar, sedangkan respon berupa reaksi atau tanggapan belajar terhadap stimulus yang diberikan oleh guru tersebut. Proses yang terjadi antara stimulus dan respon yang tidak penting unruk diperhatikan karena tidak dapat diamati dan diukur.

Yang dapat diamati adalah stimulus dan respon, oleh karena itu apa yang diberikan guru (Stimulus) dan apa yang diterima oleh pelajar (Respon) harus dapat diamati dan diukur. Teori ini mengutamakan pengukuran, sebab pengukuran merupakan suatu hal penting untuk melihat terjadi atau tidaknya perubahan tingka lakuh. Faktor lain yang dianggap penting oleh aliran lain Behavioristik adalah paktor penguatan (Reinforcement) bilah penguatan ditambahkan (Positive Reinforcement) maka respon akan semakin kuat. Begitu pulah bilah respon dikurangi atau dihilangkan maka respon juga akan semakin kuat. 


\section{Kajian Teori}

\section{Menurut Thorndike}

belajar adalah proses interaksi antara stimulus dan respon. Stimulus adalah apa yang merangsang terjadinya kegiatan belajar seperti pikiran, perasaan, atau hal-hal lain yang dapat ditanggkap melalui alat indara. Sedagkan respon adalah reaksi yang dimunculkan peserta didik ketika belajar, yang dapat pulah berupa pikiran, perasaan, atau gerakan/tindakan. Jadi perubahan tingkah laku akibat kegiatan belajar dapat berujut konkrit, yaitu yang dapat diamati, atau tidak konkrit yaitu yang tidak dapat diamati.

Ada tiga hukum belajar yang utama menurut Thorndike, yakni: Hukum efek, hukum latihan dan hukum kesiapan. Ketiga hukum ini menjelaskan bagaiman hal-hal tertentu dapat memperkuat respons.

\section{Teori belajar menurut Watson}

belajar adalah proses interaksi antara stimulus dan respon, namun stimulus dan respon yang dimaksud harus dapat diamati dan dapat diukur. Jadi walaupun dia mengakui apa adanya perubahan-perubahan mental dalam diri seseorang selama proses belajar, namund ia menganggap faktor tersebut sebagai hal yang tidak perlu diperhitungkan karena tidak dapat diamati.

\section{Teori belajar menurut Clark Hull}

Menurutnya yaitu teori belajar menggunakan fariabel hubungan antara stimulus dan respon untuk menjelaskan pengertian belajar. Namun dia sangat terpengaru teori evolusi Charles Darwin. Bagi Hulk, seperti halnya dengan teori evolusi, semua pungsi tingkalaku bermanfaat terutama untuk menjaga agar organismen tetap bertahan hidup. Oleh sebab itu Hulk mengatakan kebutuhan biologis dan pemuasan kebutuhan biologis adalah penting dan menempati posisi sentral dalam seluruh kegiatan manusia, sehingga stimulus dalam belajar pun hampir selalu dikaitkan dengan kebutuhan biologis, walaupun respon yang akan muncul mungkin dapat berujud macam-macam.

\section{Teori belajar menurut Edwin Guthrie}

Yang utama adalah hukum kontiguiti. Yaitu gabungan stimulus-stimulus yang disertai suatu gerakan, pada waktu timbul kembali cenderung akan diikuti oleh gerakan yang sama. Gutrhie juga menggunakan fariabel hubungan stimulus dan respon untuk menjelaskan proses belajar.

\section{Teori belajar menurut Skinner}

konsep-konsep yang dikembangkan Skinner tentang belajar lebih mengungguli konsep para tokoh sebelumnya. Ia mampu menjelaskan konsep belajar secarah sederhana, namun lebih konprehensip. Menurut Skinner hubungan antara stimulus dan respon yang terjadi melalui interaksi dengan lingkungannya, yang kemudian menimbulkan perubahan tingkah laku, tidaklah sederhana yang dikemukakan tokoh sebelumnya. Skinner juga mengemukakan bahwa dengan menggunakan perubahanperubahan mental sebagai alat untuk menjelaskan tingkah laku hanya akan menambah rumitnya masalah. Sebab setiap alat digunakan perlu penjelasan demikian seterusnya.

\section{Analisis tentang teori behavioristik}


Kaum behavioris menjelaskan bahwa belajar sebagai suatu proses perubahan tingkah laku dimana reinforcement dan punishment menjadi stimulus untuk meransang pelajar dalam berperilaku. Pandangan teori bahavioristik telah cukup lama dianut oleh para pendidik. Namun dari semua teori yang ada teori Skinnerlah yang paling besar pengaruhnya terhadap perkembangan teori belajar terhadap behavioristik.

\section{Metode}

Metode yang digunakan dalam penulisan makalah ini adalah analisis data kualitatif deskriptif yaitu analisis data yang menjelaskan setiap permasalahan dan tujuan yang ingin dicapai. ${ }^{1}$ Tulisan ini mengumpulkan data-data yang bersumber dari tulisantulisan yang relevan, dan membangkitkan data yang dikumpulkan untuk dinarasikan, dan dijelaskan menjadi tulisan yang lebih komprehensif. ${ }^{2}$ Dengan teori behavioristic yang dihubungkan dengan kebenaran firman Tuhan akan diperoleh data-data yang lebih dekat untuk menjelaskan perjumpaan yang mengubahkan.

Prosedur yang dilakukan adalah melakukan prosedur 5P (penghubung, Pelajaran, Penerapan, Perubahan, dan Penutup). Ini dsebut dengan Belajar berarti berubah (Learning that LASTS). ${ }^{3}$ Model pembelajaran yang lain juga dapat diterangkan seperti model pembelajaran kooperatif STAD,${ }^{4}$ metode Muhaddrah untuk meningkatkan motivasi siswa dalam belajar. ${ }^{5}$ Dalam proses pembelajaran 5P diharapkan peserta didik dapat memperbaiki perilaku, motivasi, dan sikap, karakter peserta didik. ${ }^{6}$

\section{Pembahasan}

Perjumpaan Yang Mengubahkan

FOKUS: Bagaimana peserta didik belajar dapat berpikir, bersikap, dan bertindak setelah mengalami sendiri firman Tuhan.

1. Penghubung: pengalaman yang mengubahkan

(semua siswa membuka Alkitab di dalam Kis 9:1-19). Siswa membentuk 3

kelompok lalu berdiskusi. Selama mendengar cerita ini pikirkan, rasakan, dan lakukan bagian firman Tuhan tersebut. Guru membacakan nas Kis 9:9-19 lalu setiap kelompok mendengarkan.

Ceritalah:bagaimana perasaan saudara tentang kejadian yang di alami Paulus?

\footnotetext{
${ }^{1}$ Hengki Wijaya, Metode Penelitian Pendidikan Teologi (Makassar: Sekolah Tinggi Theologia Jaffray Makassar, 2013).

${ }^{2}$ Hengki Wijaya and Helaluddin Helaluddin, Analisis Data Kualitatif Sebuah Tinjauan Teori \& Praktik (Makassar: Sekolah Tinggi Theologia Jaffray Makassar, 2019).

${ }^{3}$ Roland Walker, "Learning That LASTS," n.d., https://wycliffe.fi/wpcontent/uploads/2018/12/intro-to-learning-that-lasts-walker.pdf.

${ }^{4}$ Hengki Wijaya and Arismunandar Arismunandar, "Pengembangan Model Pembelajaran Kooperatif Tipe STAD Berbasis Media Sosial,” Jurnal Jaffray 16, no. 2 (October 6, 2018): 175-96, https://doi.org/10.25278/jj71.v16i2.302.

${ }^{5}$ Nurmadiah Nurmadiah et al., "Enhancing Students' Motivation to Learn Arabic Through Method of Muhadharah," in First International Conference on Culture, Education, Linguistics and Literature, CELL 2019 (Proceedings of First International Conference on Culture, Education, Linguistics and Literature, CELL 2019, 5-6 August, Purwokerto, Central Java, Indonesia, Purwokerto, Central Java, Indonesia: EAI, 2019), https://doi.org/10.4108/eai.5-8-2019.2289818.

${ }^{6}$ Hengki Wijaya and Helaluddin Helaluddin, "Hakikat Pendidikan Karakter," 2018, https://repository.sttjaffray.ac.id/id/publications/269450/hakikat-pendidikan-karakter.
} 
2. Pelajaran: perjumpaan yang mengubah

Setiap kelompok berdiskusi lalu Ceritakanlah perubahan yang di alami Saulus saat berjumpa dengan Tuhan Yesus, tuliskan pada pada Sticker note kata kunci untuk menunjukkan usaha tersebut. ${ }^{7}$ Tempelkan sticker note di depan.

setiap siswa yang menjawab benar di kasih hadiah. Sebaliknya setiap siswa yang salah akan di hukum.

3. Penerapan: kesaksian masing-masing siswa

Masing-masing 1 orang mewakili dalam kelompok bersaksi di depan kelas tentang bagaimana Tuhan mengubahkan kehidupannya (2-3 menit). ${ }^{8}$

4. Perubahan: tindakan setelah diubahkan setiap siswa menuliskan perubahan yang di alami setelah bertobat (hidup baru). ${ }^{910}$

Tuliskan komitmen saudara setelah bertobat. Tempelkan pada stick note di dalam Alkitab saudara pada nas tersebut.

5. Penutupan ${ }^{11}$

Nyanyian lagu "rukun Cinta"

Rukun cinta satu sama lain

Itulah maunya Tuhan

Rendah hati serta rama tamah

Itulah maunya Tuhan

Reef : tunjukan saksikan Tuhan minta buktinya

Tunjukan saksikan Tuhan minta buktiNya

\section{Kesimpulan}

Perjumpaan dengan Allah adalah sesuatu yang menyenangkan, dan setiap orang percaya merindukan hal itu terjadi dalam hidupnya. Untuk itulah setiap peserta didik harus memiliki perjumpaan dengan Allah, dan dirindukan terus-menerus dalam hidup kekristenan. Guru menstimulus siswa untuk memiliki hubungan dengan Allah karena Allah saja yang dapat mengubahkan hidupnya.

Perjumpaan dengan Allah adalah manusia baru yang sudah diubahkan oleh RohNya. Dalam belajar ada pimpinan Tuhan yang akan mendorong setiap orang percaya untuk mencari Allah dan kehendak-Nya sehingga sikap dan perilaku siswa dapat diubahkan dan berdampak pada hasil belajar siswa.

\footnotetext{
${ }^{7}$ Hengki Wijaya, "Ulasan Buku: Whatever Happened To Worship A Call To True Worship," Jurnal Jaffray 15, no. 1 (March 19, 2017): 148, https://doi.org/10.25278/jj71.v15i1.241.

${ }^{8}$ Hengki Wijaya, "Mengapa Allah Memakai Dwight Lyman Moody? Kisah Hidup Seorang Pelayan Sekolah Minggu," Jurnal Jaffray 10, no. 2 (October 1, 2012): 180, https://doi.org/10.25278/jj71.v10i2.52.

${ }^{9}$ Elsyana Nelce Wadi and Elisabet Selfina, "Peran Orang Tua Sebagai Keluarga Cyber Smart Dalam Mengajarkan Pendidikan Kristen Pada Remaja GKII Ebenhaezer Sentani Jayapura Papua,” Jurnal Jaffray 14, no. 1 (March 14, 2016): 77-92, https://doi.org/10.25278/jj71.v14i1.190.

${ }^{10}$ Jonathan Matheus and Elisabet Selfina, "Peran Pembina Remaja Bagi Perkembangan Perilaku Remaja Di Gereja Kemah Injil Indonesia Tanjung Selor Kalimantan Utara,” Jurnal Jaffray 13, no. 1 (January 31, 2015): 1-22, https://doi.org/10.25278/jj71.v13i1.3.

${ }^{11}$ Rohani Siahaan, “Analisis Pengaruh Nyanyian Jemaat Terhadap Kualitas Ibadah Gereja Protestan di Indonesia bagian Barat (GPIB) Jemaat Bukit Zaitun Makassar," Jurnal Jaffray 11, no. 2 (October 2, 2013): 140-64, https://doi.org/10.25278/jj71.v11i2.82.
} 


\section{Daftar Pustaka}

Matheus, Jonathan, and Elisabet Selfina. "Peran Pembina Remaja Bagi Perkembangan Perilaku Remaja Di Gereja Kemah Injil Indonesia Tanjung Selor Kalimantan Utara." Jurnal Jaffray 13, no. 1 (January 31, 2015): 1-22. https://doi.org/10.25278/jj71.v13i1.3.

Nurmadiah, Nurmadiah, Sitti Sakinah, Helaluddin Helaluddin, and Hengki Wijaya. "Enhancing Students' Motivation to Learn Arabic Through Method of Muhadharah." In First International Conference on Culture, Education, Linguistics and Literature, CELL 2019. Purwokerto, Central Java, Indonesia: EAI, 2019. https://doi.org/10.4108/eai.5-8-2019.2289818.

Siahaan, Rohani. "Analisis Pengaruh Nyanyian Jemaat Terhadap Kualitas Ibadah Gereja Protestan di Indonesia bagian Barat (GPIB) Jemaat Bukit Zaitun Makassar." Jurnal Jaffray 11, no. 2 (October 2, 2013): 140-64. https://doi.org/10.25278/jj71.v11i2.82.

Wadi, Elsyana Nelce, and Elisabet Selfina. "Peran Orang Tua Sebagai Keluarga Cyber Smart Dalam Mengajarkan Pendidikan Kristen Pada Remaja GKII Ebenhaezer Sentani Jayapura Papua.” Jurnal Jaffray 14, no. 1 (March 14, 2016): 77-92. https://doi.org/10.25278/jj71.v14i1.190.

Walker, Roland. "Learning That LASTS," n.d. https://wycliffe.fi/wpcontent/uploads/2018/12/intro-to-learning-that-lasts-walker.pdf.

Wijaya, Hengki. "Mengapa Allah Memakai Dwight Lyman Moody? Kisah Hidup Seorang Pelayan Sekolah Minggu.” Jurnal Jaffray 10, no. 2 (October 1, 2012): 180. https://doi.org/10.25278/jj71.v10i2.52.

Wijaya, Hengki. Metode Penelitian Pendidikan Teologi. Makassar: Sekolah Tinggi Theologia Jaffray Makassar, 2013.

Wijaya, Hengki. "Ulasan Buku: Whatever Happened To Worship A Call To True Worship." Jurnal Jaffray 15, no. 1 (March 19, 2017): 148. https://doi.org/10.25278/jj71.v15i1.241.

Wijaya, Hengki, and Arismunandar Arismunandar. "Pengembangan Model Pembelajaran Kooperatif Tipe STAD Berbasis Media Sosial." Jurnal Jaffray 16, no. 2 (October 6, 2018): 175-96. https://doi.org/10.25278/jj71.v16i2.302.

Wijaya, Hengki, and Helaluddin Helaluddin. Analisis Data Kualitatif Sebuah Tinjauan Teori \& Praktik. Makassar: Sekolah Tinggi Theologia Jaffray Makassar, 2019.

Wijaya, Hengki. "Hakikat Pendidikan Karakter," 2018. https://repository.sttjaffray.ac.id/id/publications/269450/hakikat-pendidikankarakter. 